\title{
LOVE AS INFORMATION AND ENERGY UNIT OF PERSON'S HAPPINESS
}

In Happiness And Contemporary Society : Conference Proceedings Volume (Lviv, March, 20-21, 2021). Lviv: SPOLOM, 2021. P. 179-181. https://doi.org/10.31108/7.2021.41

ISBN 978-966-919-697-2

\section{ЛЮБОВ ЯК ІНФОРМАЦІЙНО- ЕНЕРГЕТИЧНА ОДИНИЦЯ ЩАСТЯ ОСОБИСТОСТІ}

// Щастя та сучасне суспільство : збірник матеріалів міжнародної наукової конференції (Львів, 20-21 березня 2021 р.). - Львів : СПОЛОМ, 2021. С. 179-181. https://doi.org/10.31108/7.2021.41

ISBN 978-966-919-697-2 
https://doi.org/10.31108/7.2021.41

\section{MAKSYMENKO Serhii}

Doctor of Psychological Sciences, Professor, Academician of NAES of Ukraine

Director of G.S. Kostiuk Institute of Psychology of NAES of Ukraine

(Kyiv, Ukraine)

\section{LOVE AS INFORMATION AND ENERGY UNIT OF PERSON'S HAPPINESS}

Love is a core of personality. Love is foundation and systemicity that integrates in itself motivations, content and purpose. Love is all-embracing and represents actuality of happiness. The top experience of love is what is called "experience of flow" in the contemporary psychology. A person is excited and driven by the flow of life itself. Goals, strivings and anticipations disappear - everything submits to the flow, the motion that becomes the most important and essential itself.

Keywords: happiness, development, love, dynamics, becoming, an individual, productivity.

\section{МАКСИМЕНКО Сергій}

доктор психологічних наук, професор, академік НАПН Украӥни, Директор Інситуту психології Г.С. Костюка НАПН Украӥни (Київ, Украӥна)

\section{ЛЮБОВ ЯК ІНФОРМАЦЙНО-ЕНЕРГЕТИЧНА ОДИНИЦЯ ЩАСТЯ ОСОБИСТОСТІ}

Любов виступає як ядерне утворення особистості. Любов $\epsilon$ тією основою,системністю яка поєднує в собі і мотивації і контент і ціль. Вона всеохоплююча і являється дійсністю щастя. , Вершинне переживання любові є тим, що в сучасній психології дістало назву “переживання потоку”. Людину підхоплює i захоплює плин самого життя, зникають як такі цілі, прагнення, властивості i передбачення - все підкоряється течії, руху, який сам по собі стає найважливішим, найсуттєвішим.

Ключові слова: щастя, розвиток, любов, динаміка, становлення, індивід, продуктивність.

Особистість розглядається в розвитку та динаміці. Вона має свої витоки, свій початок і $є$ продуктом того переливання нужди в одну істоту двох людей,які люблять один одного. В цьому контексті , продовженням роду є особистості ,від кого і від чого залежить краса, природна здатність, духовна делікатність особистості. Варто дати визначення, особистості - вона $є$ формою існування психіки , як цілісності, яка здатна до саморозвитку, свідомої предметної діяльності, самовизначення і самоздійснення і має свій унікальний , неповторний світ.

В цьому унікальному, неповторному світі відображаються всі: генотипічні ,природні, анатомо-фізіологічні задатки, якості і властивості особистості іiі вищі психічні функції пари людей. Навіть створюється «зачаровне коло», харизма , яка має характерологічні особливості особистості. Прояви цієї індивідуальності ,яка народжується вже особистістю. В такому контексті правомірно говорити, що все треба формувати , вчити любити 3 дитинства i привласнювати різні 
здібності.Формувати мовно-етнічну ідентичність, як складову держави. Тут і відбувається відтворюється непохитно резистентна властивість народженій істоті, яка в соціальному аспекті існує вічно як особистість. Це і є національна ідентичність та національність.

Утворюються природні переплетіння: архетипу, задатків, природних здатностей, які можуть бути здійснені в процесі життя і діяльності. В цьому зв’язку хотілося б сказати,що вся ця різноманітність красива , заземлена, природня , духовна , соціальні і біологічна дають підстави для роздумів дослідників, які по різному визначають особистість.

Особистість визначється, як свідомий індивід, що займає певне місце в суспільстві, виконує певну роль чи функцію. Як соціокультурна властивість людини , на базі іï природної організації з притаманними ій вищими психічними функціями і певними особливостіми. Варто сказати, що індивідуальністю народжуються ,а особистістю стають. Культур багато, а культурних людей нажаль мало. I в цьому зв'язку розглядаються проблеми понятійних, семантичних, праксичних структур особистості. Коли ми розглядаємо особистість, як належну до того чи іншого етносу національності, постає питання що таке національність. Що таке етнос? Це проста річ. Історія особистості це і $є$ нація- основна ідентичність та національність.

Саме в культурі, історії особистості, як у краплі роси висвічуються і архетип , і природні ,i соціальні, і суспільні особливості. В ньому повторюється географічне середовище в якому знаходяться особистості. I в силу соціальних обставин воно привласнює все геополітичне , культурне і природне середовище, на що вказує поява талантів в художньому , культурному та в науковому смислах. А саме прояв ранніх здібностей : мистецьких, природної обдарованості, яка полягає в доброзичливості ставлення до природи ,до культури і саме головне до інших людей, оскільки природа найбільш досконалий конструкт , що є вічним. Люди на землі зявляються, проходять екскурсійний шлях ,спостерігаючи в свої пошуках культурні надбання власної національної ідентичності особистості.

Пошуки по тим чи іншим роздумам, привласненням тих чи інших цінностей. Все проходить , оскільки біологічно людська організація зникає так як проходить день, за днем наступає ніч, але за скінченністю особистсоті немає меж.

"Особистість починається 3 любові" - ця теза суперечить вихідному положенню вітчизняної психології щодо онтогенезу особистості, яке було втілено в назву статті О.М.Леонтьєва "Начало личности - поступок" і дало поштовх цілому напряму української “психології вчинку". Вчинок, якщо його брати в розумінні О.М.Леонтьєва i В.А.Роменця, ніколи не може бути "началом особистості”, оскільки для того, щоб його здійснити, треба вже бути особистістю: усвідомлювати власне “Я”, усвідомлювати “Я Іншого” і якось ставитись до нього.

Началом особистості $\epsilon$ не вчинок, ним $є$ любов. "Без любові, - говорить П.Флоренський, - особистість розсипається в дрібність психологічних елементів і моментів. Любов - з'єднуюча ланка особистості'. Любов об'єднує i, власне, створює особистість завдяки тому, що не дає людині зосередитись на власному

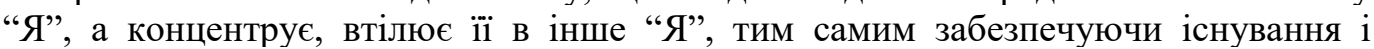
розвиток себе як цілісності. О.Ф.Лосєв відзначав, що головними прагненнями особистості $є$ абсолютне самоствердження, внутрішня свобода, цілісність i гармонійність. "Вона бажає існувати так, як існують боги, що споглядають безкінечний світ і розумну тишу свого, ні від чого не залежного, світлого буття”. I 
це існування стає можливим в любові. Лосєв продовжує: “І ось, коли чуттєва i строкато-випадкова історія особистості, зануреної у відносне, напівтемне, безсиле i хворобливе існування, раптом приходить до події, в якій виявляється ця відпочаткова i укорінена, світла призначеність особистості, пригадується втрачений всезагальний стан і тим долається стомлююча порожнеча і строкатий гамір емпірії - тоді це означає, що твориться диво. Любов, iii переживання і iіi прагнення і $є$ цим дійсним дивом. Р.Мей зазначає, що любов несе в собі невимірювану психологічну енергію. I це є найбільш могутня сила для здійснення впливу і трансформації особистості.

Але так любити, цілком слушно вважає Е.Фромм, може далеко не кожна людина. Така любов "передбачає, що особистість повинна сформувати в себе переважну установку на плідну діяльність, подолавши залежність, самозакоханість, схильність до накопичування і до маніпулювання іншими". Людина повинна повірити у власні сили, бути самодостатньою у досягненні мети. I крім того, що любити - означає завжди віддавати, “це завжди означає також піклуватися, нести відповідальність, поважати і знати... це найважливіші риси любові, притаманні всім ії формам”. Тепер зрозуміло, що по-справжньому любити здатна лише зріла, відкрита і продуктивна особистість. Але чому ж тоді ми вважаємо любов початком особистості? Ми можемо підсилити тезу: любов є не просто початком особистості, вона існує раніше особистості, і вона породжує (визначає, детермінує) процес їі створення (як дива).

В цілому, наша думка щодо впливу любові на становлення особистості в онтогенезі, хоча у значній мірі й гіпотетична, грунтується на серйозних положеннях. Може виникнути питання конкретного характеру: чим саме негативним може бути відсутність любові між людьми при “створенні” ними нового життя? Не вдаючись до подробиць (що було б безвідповідально за умови відсутності емпіричних наукових фактів), ми наважимось на припущення: страх любові і “втеча" від неї, неспроможність побудувати стосунки, відмова від зростання і самореалізації - чи не є це все наслідком народження людини не в любові?! І коло знову замикається.

$€$ ще один суттєвий аспект. Ми зовсім не бажаємо сказати, що все в житті i становленні особистості визначається відпочатковим актом іiї створення і станом, в якому знаходились батьки. Це, взагалі то, не так. Існування особистості як соціального феномена, що саморозвивається шляхом врощення себе в культуру, актуалізації власних біосоціальних потенцій і творчого осягнення світу, має багато можливостей компенсувати існуючий недолік і зростати в любові з боку інших і до інших. На всіх етапах онтогенезу особистості потенційно надаються такі можливості, і iï власна справа - використати їх. Хоча досвід вчить, що дефіцит любові в ранньому дитячому віці компенсувати буває дуже непросто.

На завершення необхідно відзначити, що ця проблема є дуже важливою, але, водночас, і гостро проблематичною. Генетико-моделюючий підхід до розуміння дійсних механізмів онтогенезу особистості визначає необхідність науковопсихологічного аналізу такого складного і важливого феномену, яким є людська любов. Разом з тим, відсутність емпіричних досліджень (а отже, і даних) змушує сполучати в аналізі вихідні теоретико-філософські положення, спостереження, які проводяться в консультативній роботі, та житейський досвід. Звідси проблематичність і дискусійність викладеного, в чому ми повністю віддаємо собі звіт. Але ж дискусія - не найгірший шлях розвитку науки. 